\title{
The prognostic value of 4.1 mRNA expression in non-small cell lung cancer
}

\author{
Yuying Xiang ${ }^{1 \#}$, Feiyu Shan ${ }^{2 \#}$, Guan Feng ${ }^{1}$, Kaibo Guo ${ }^{1}$, Shanming Ruan ${ }^{3}$, Dawei Huang ${ }^{4}$ \\ ${ }^{1}$ The First Clinical Medical College of Zhejiang Chinese Medical University, Hangzhou, China; ${ }^{2}$ First Affiliated Hospital of Wenzhou Medical \\ University, Wenzhou, China; ${ }^{3}$ Department of Oncology, The Forth Clinical Medical College of Zhejiang Chinese Medical University, Hangzhou, \\ China; ${ }^{4}$ The First Affiliated Hospital of Zhejiang Chinese Medical University, Hangzhou, China \\ Contributions: (I) Conception and design: Y Xiang, F Shan; (II) Administrative support: G Feng; (III) Provision of study materials or patients: K \\ Guo; (IV) Collection and assembly of data: D Huang; (V) Data analysis and interpretation: S Ruan; (VI) Manuscript writing: All authors; (VII) Final \\ approval of manuscript: All authors. \\ \#These authors contributed equally to this work. \\ Correspondence to: Dawei Huang. The First Affiliated Hospital of Zhejiang Chinese Medical University, Hangzhou, China. Email: hdw1986@163.com.
}

Background: The mechanism of 4.1 family in human cancer has not been elucidated. In this study we investigate the value as a prognostic factor of mRNA expression of 4.1 family in non-small cell lung cancer (NSCLC).

Methods: A survival analysis was carried out through the Kaplan-Meier plotter (KM plotter) database. KM's method was used to estimate the prognostic value of $4.1 \mathrm{mRNA}$ expression in NSCLC.

Results: Expression of four members are linked to overall survival (OS) in NSCLC patients, among which 4.1G, 4.1B, 4.1R are concerned with first progression (FP), and 4.1G, 4.1R are correlated with post progression survival (PPS) besides. Only 4.1B expression is associated with OS in squamous cell carcinoma, as four members with OS in adenocarcinoma. What's more, 4.1G, 4.1N high mRNA are linked to better FP in adenocarcinoma, and 4.1R overexpression is linked to better PPS. The expression of $4.1 \mathrm{G}$ is associated with the prognosis in female, whereas $4.1 \mathrm{R}$ in male. Furthermore, $4.1 \mathrm{G}$ and $4.1 \mathrm{~B}$ play as protective roles in non-smoking populations, while $4.1 \mathrm{~N}$ overexpression is related to poorer PPS. All the four family members are associated with early stage in NSCLC 4.1G, 4.1B and 4.1R are closely related to surgical resection, yet 4.1N has no prognostic significance in patients receiving treatments. However, the results need to be verified in clinical trials further.

Conclusions: Our results offer new opinion about the prognostic value of 4.1 protein family in NSCLC, which may contribute to the development of new therapy for NSCLC.

Keywords: 4.1 mRNA; prognosis; non-small cell lung cancer (NSCLC); Kaplan-Meier plotter (KM plotter)

Submitted Jul 09, 2020. Accepted for publication Jan 22, 2021.

doi: $10.21037 /$ tcr-20-2501

View this article at: http://dx.doi.org/10.21037/tcr-20-2501

\section{Introduction}

Lung cancer is the leading cause of mortality in both female and male, and a total of 234,030 new cases and 154,050 mortalities are estimated to occur in the United States in 2018 (1). Lung cancer is classified as small cell lung cancer (SCLC) and non-small cell lung cancer (NSCLC), and NSCLC accounts for $80-85 \%$ of the total cases (2). Even though a great number of clinical trials are designed to target potential oncogenes such as KRAS, BRAF, HER2, PI3KCA and MET in the past decade, the 5-year overall survival (OS) has not been significantly changed $(2,3)$. Therefore, searching for biological targets that may effectively improve therapy and prognosis is the key to the treatment of NSCLC.

The protein 4.1 family including the $4.1 \mathrm{R}$ (mainly expressed in red cell), $4.1 \mathrm{~N}$ (neuron-specific expression), 
4.1G (broad expression) and 4.1B (mainly in the brain), which are encoded by the EPB41 genes, are components of the cortical cytoskeleton underlying the cell membrane (4). 4.1 proteins have conserved domains, including $\mathrm{N}$-terminal FERM domain (membrane-binding domain-MBD domain), spectrin-actin binding domain (SAB domain), C-terminal domain (CTD structure domain) (5). Those domains can link to cortical cytoskeleton via binding of some cell cortex nodes, such as actin protein, spectrin, transmembrane adhesion protein and other family proteins, to regulate not only the polarity, adhesion and motility of the tissue cells, but also the trans-membrane transport. Recently, a variety of researchers have found that 4.1 protein is closely connected with the occurrence and development of tumors. It has been reported that abnormal expression of 4.1 protein exists in various types of tumors such as NSCLC, breast cancer, liver cancer and prostate cancer (6-9).

Kaplan-Meier plotter (KM plotter) (http://kmplot.com/ analysis/), created by Györffy et al. (10), is an online survival analysis software used to evaluate the prognostic significance of biomarkers. In this study, we used KM plotter to assess the prognostic value of mRNA expression of each member of protein 4.1 in NSCLC, and the correlation with smoking history, OS, pathological grades, clinical stages and clinical therapy.

We present the following article in accordance with the REMARK reporting checklist (available at http://dx.doi. org/10.21037/tcr-20-2501).

\section{Methods}

\section{Materials and data}

We used KM plotter, which includes 2,437 lung cancer patients with a mean follow-up of 49 months, to determine the prognostic values of $4.1 \mathrm{~s}$ in lung cancer.

\section{Statistical analysis}

We collected the baseline data including number of cases, histology, stage, gender, smoking history, therapeutic regimen as well as hazard ratio $(\mathrm{HR}), 95 \%$ confidence interval (CI) and log-rank $\mathrm{P}$ values. $\mathrm{P}<0.05$ was considered statistically significant.

The study was conducted in accordance with the Declaration of Helsinki (as revised in 2013). All data in the database is publicly available and exempt from Institutional Review Board review.

\section{Results}

\section{Prognostic value of 4.1 s in NSCLC}

4.1 family members existing in NSCLC patients were found in the database (Figure 1). From the survival curves, we found that high level of mRNA expression of $4.1 \mathrm{G}$ $(\mathrm{HR}=0.75,95 \% \mathrm{CI}: 0.66-0.86, \mathrm{P}=1.2 \mathrm{e}-05), 4.1 \mathrm{~B}(\mathrm{HR}$ $=0.84,95 \% \mathrm{CI}: 0.74-0.95, \mathrm{P}=0.0058), 4.1 \mathrm{~N}(\mathrm{HR}=0.8$, 95\% CI: 0.71-0.91, P=0.00083), 4.1R ( HR =0.59, 95\% CI: $0.5-0.7, \mathrm{P}=6.2 \mathrm{e}-10)$ were associated with a more favorable prognosis.

Furthermore, our results showed that the overexpression of 4.1G ( $\mathrm{HR}=0.73,95 \% \mathrm{CI}: 0.60-0.88, \mathrm{P}=0.001), 4.1 \mathrm{~B}(\mathrm{HR}$ $=0.78,95 \%$ CI: $0.65-0.95, \mathrm{P}=0.013), 4.1 \mathrm{R}(\mathrm{HR}=0.54,95 \%$ CI: $0.41-0.72, \mathrm{P}=1 \mathrm{e}-05)$ were related to better $\mathrm{FP}$, except $4.1 \mathrm{~N}$ (HR $=1.02$, 95\% CI: $0.85-1.24, \mathrm{P}=0.81)$. At the same time, the high expression of $4.1 \mathrm{G}(\mathrm{HR}=0.78,95 \% \mathrm{CI}$ : 0.6-1.0, $\mathrm{P}=0.049$ ) and 4.1R (HR =0.45, 95\% CI: 0.29-0.70, $\mathrm{P}=0.00023)$ forebode longer PPS, while overexpression of 4.1B (HR =0.88, 95\% CI: 0.68-1.14, $\mathrm{P}=0.33)$ and 4.1N (HR $=1.01,95 \%$ CI: $0.78-1.30, \mathrm{P}=0.96)$ were unrelated to PPS.

\section{Prognostic value of 4.1 members in different NSCLC subtypes}

There are two different intrinsic subtypes of NSCLC including squamous cell carcinoma and adenocarcinoma in the database (Figure 2). As for patients with squamous cell carcinoma, 4.1B $(\mathrm{HR}=0.78,95 \% \mathrm{CI}: 0.62-0.99, \mathrm{P}=0.041)$ mRNA expression level was connected with improved OS, whereas 4.1G (HR =0.85, 95\% CI: 0.67-1.08, $\mathrm{P}=0.18)$, 4.1R $(\mathrm{HR}=0.84,95 \% \mathrm{CI}: 0.61-1.14, \mathrm{P}=0.25)$ and $4.1 \mathrm{~N}(\mathrm{HR}$ $=0.81,95 \%$ CI: $0.64-1.03, \mathrm{P}=0.078)$ not. Furthermore, the high expression of four members were not associated with FP (4.1G: HR =0.77, 95\% CI: 0.46-1.28, P=0.31; 4.1B: HR $=0.84$, 95\% CI: $0.5-1.4, \mathrm{P}=0.49 ; 4.1 \mathrm{~N}: \mathrm{HR}=0.94,95 \% \mathrm{CI}$ : $0.57-1.58, \mathrm{P}=0.83 ; 4.1 \mathrm{R}: \mathrm{HR}=0.82,95 \% \mathrm{CI}: 0.49-1.37$, $\mathrm{P}=0.44$ ) or $\mathrm{PPS}$ (4.1G: $\mathrm{HR}=1.74,95 \% \mathrm{CI}: 0.59-5.09$, $\mathrm{P}=0.31$; 4.1B: $\mathrm{HR}=1.29,95 \% \mathrm{CI}: 0.46-3.60, \mathrm{P}=0.63 ; 4.1 \mathrm{~N}$ : $\mathrm{HR}=1.57,95 \%$ CI: $0.54-4.54, \mathrm{P}=0.41 ; 4.1 \mathrm{R}: \mathrm{HR}=1.03$, 95\% CI: 0.36-2.98, $\mathrm{P}=0.95)$ in squamous cell carcinoma.

In adenocarcinoma patients, however, high mRNA expression of 4.1 members (4.1G: $\mathrm{HR}=0.57,95 \% \mathrm{CI}$ : $0.45-0.73, \mathrm{P}=5 \mathrm{e}-06$; 4.1B: $\mathrm{HR}=0.59$, 95\% CI: 0.47-0.75, $\mathrm{P}=1 \mathrm{e}-05 ; 4.1 \mathrm{~N}: \mathrm{HR}=0.66$, 95\% CI: $0.52-0.85, \mathrm{P}=8 \mathrm{e}-04)$ were significantly related to $\mathrm{OS}$, especially the $4.1 \mathrm{R}$ (HR $=0.4,95 \%$ CI: $0.31-0.52, \mathrm{P}=7.2 \mathrm{e}-13)$. Except 4.1B (HR $=0.86,95 \% \mathrm{CI}: 0.63-1.18, \mathrm{P}=0.35)$, high expression of 
A

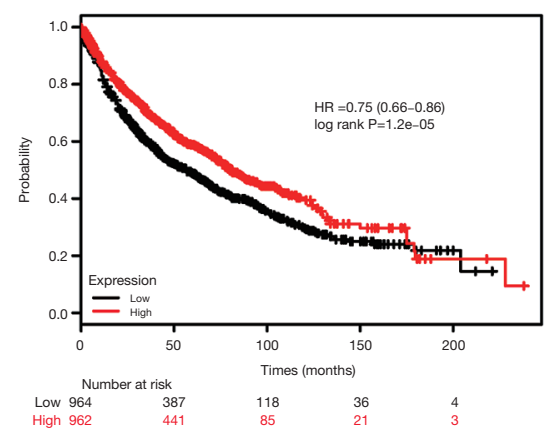

D

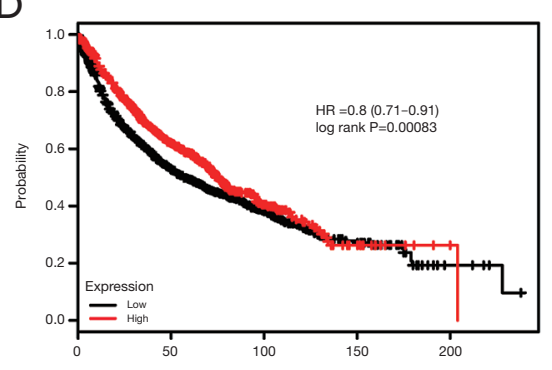

\begin{tabular}{ccccc}
\multicolumn{3}{c}{ Number at risk } & \multicolumn{3}{c}{ Times (months) } \\
Low 965 & 410 & 132 & 43 & 5 \\
High 961 & 418 & 71 & 14 & 2
\end{tabular}

G

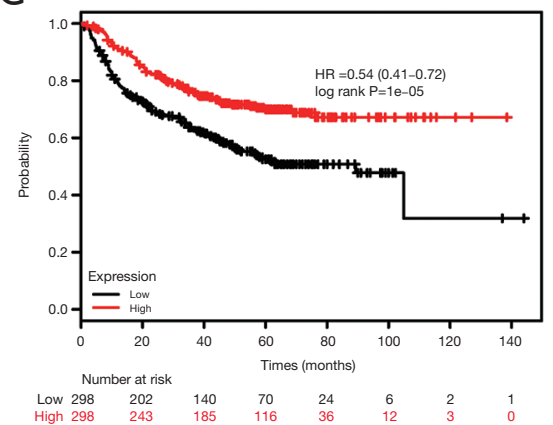

J

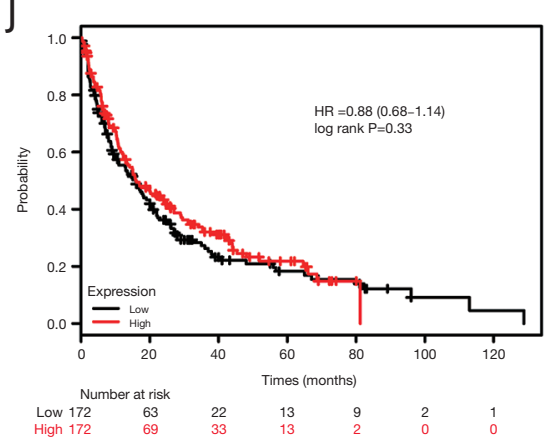

B

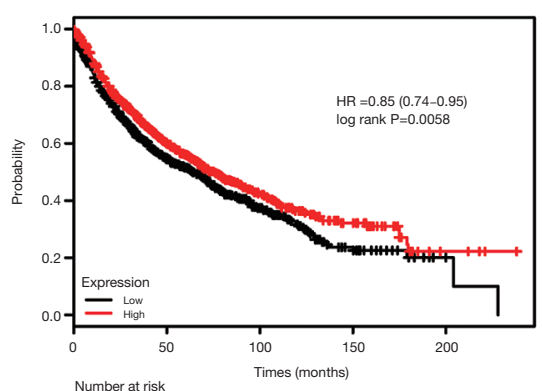

\begin{tabular}{ccccc}
\multicolumn{2}{c}{ Number at risk } & \multicolumn{3}{c}{ Times (months) } \\
Low 967 & 375 & 98 & 22 & 3 \\
High 959 & 453 & 105 & 35 & 4
\end{tabular}

E
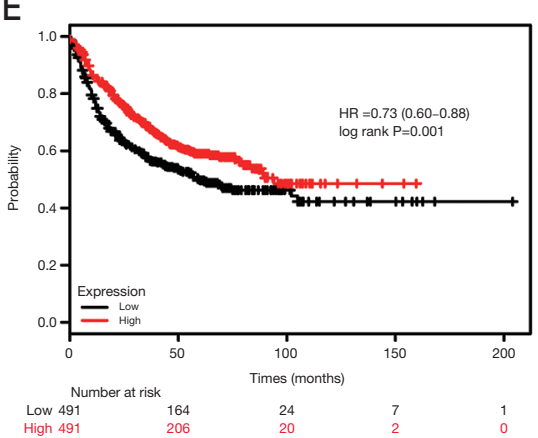

$\mathrm{H}$

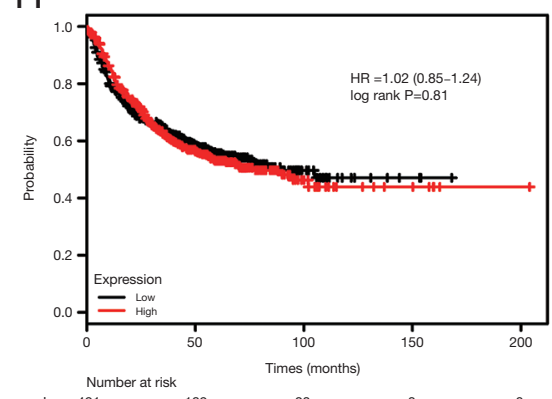

\begin{tabular}{ll}
\multicolumn{3}{c}{ Number at risk } \\
Low 491 & 189 \\
High 491 & 181
\end{tabular}

$\mathrm{K}$

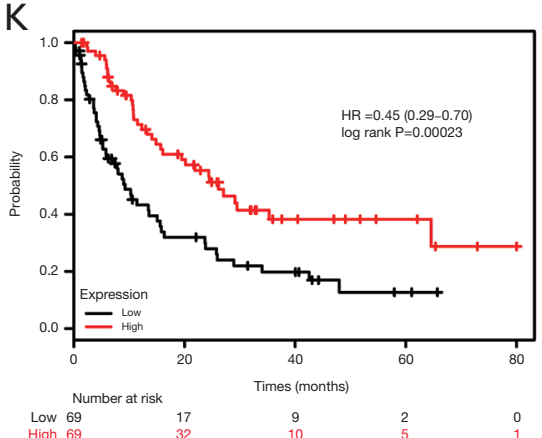

C

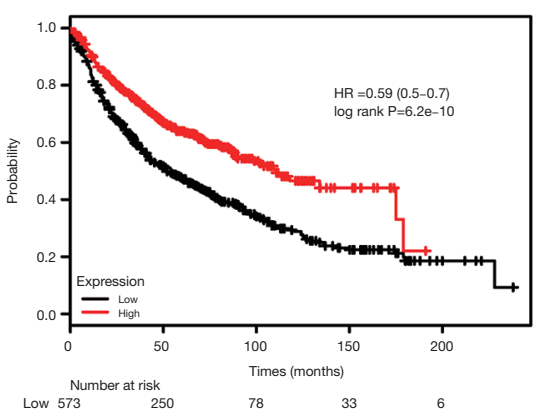

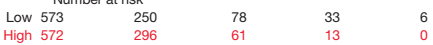

$\mathrm{F}$

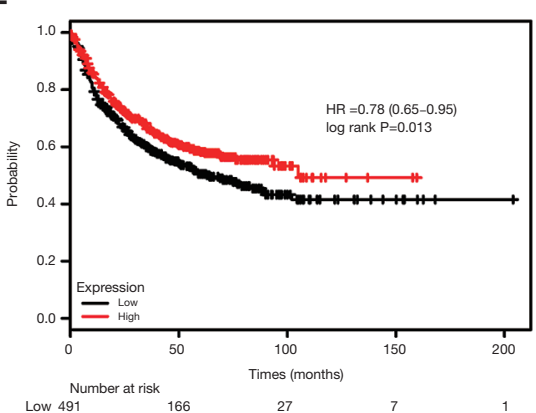

\begin{tabular}{ll}
\multicolumn{2}{c}{ Number at risk } \\
Low 491 & 166 \\
High 491 & 204
\end{tabular}

I

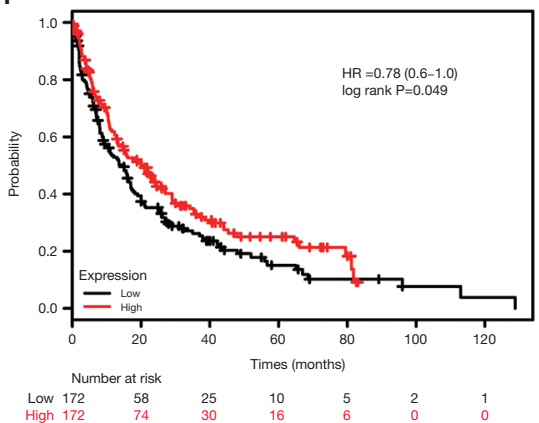

$\mathrm{L}$

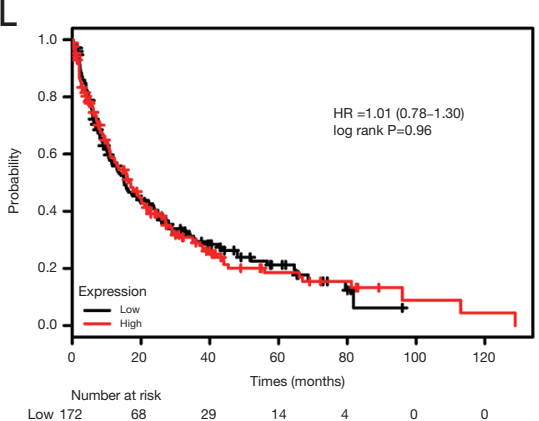

Figure 1 The prognostic roles of 4.1 in NSCLC. (A,B,C,D) High mRNA expression of 4.1G, 4.1B, 4.1R, 4.1N were significantly associated with better OS. (E,F,G,H) The relationship of 4.1G, 4.1B, 4.1R, 4.1N with FP. (I,J,K,L) The relationship of 4.1G, 4.1B, 4.1R, 4.1N with PPS. HR, hazard ratio; NSCLC, non-small cell lung cancer; OS, overall survival; FP, first progression; PPS, post progression survival. 
A

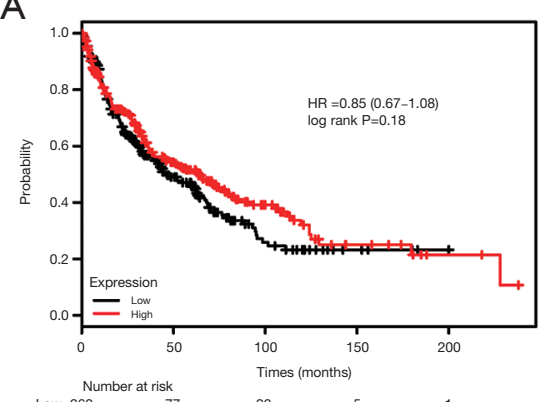

$\begin{array}{crcc} & \text { Number at risk } & & \\ \text { Low } 262 & 77 & 20 & 5 \\ \text { High } 262 & 102 & 34 & 10\end{array}$

D

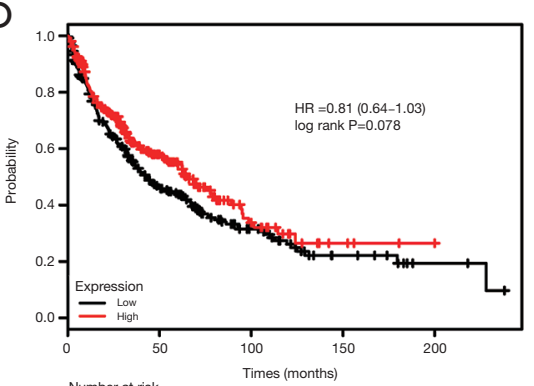

\begin{tabular}{lllll}
\multicolumn{2}{c}{ Number at risk } & \multicolumn{3}{l}{ Times (months) } \\
Low 263 & 93 & 33 & 11 & 3 \\
High 261 & 86 & 21 & 4 & 1
\end{tabular}

G

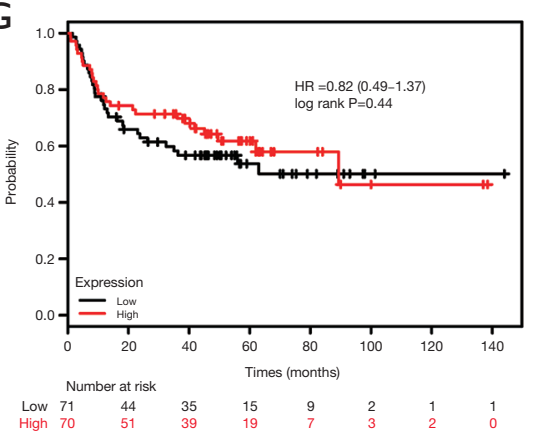

J

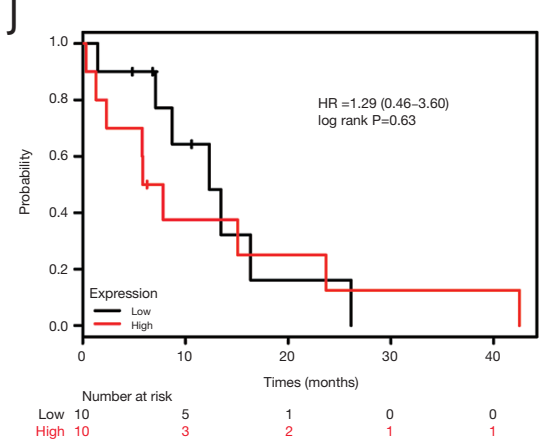

B
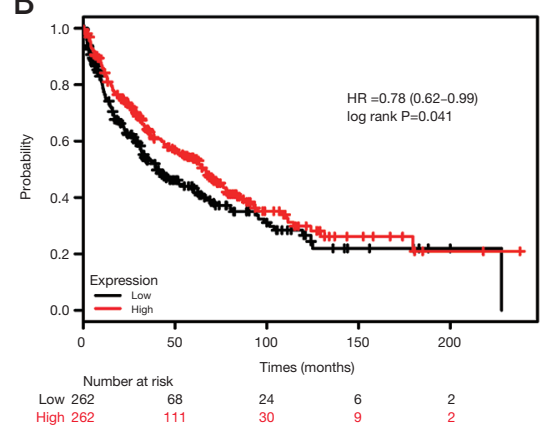

E
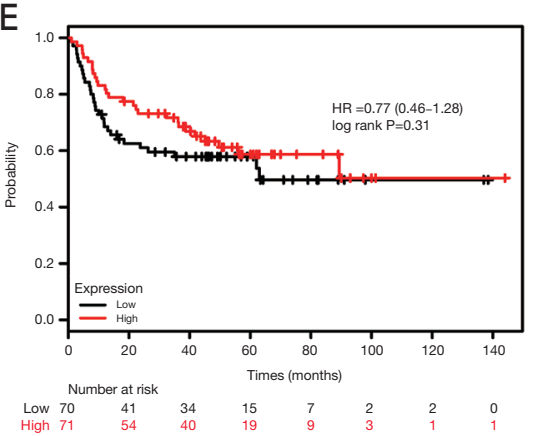

$\mathrm{H}$

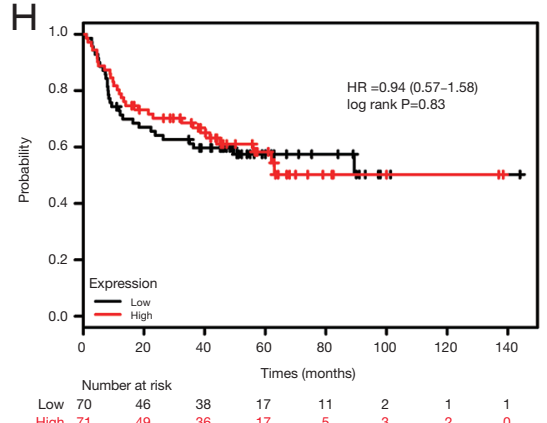

K

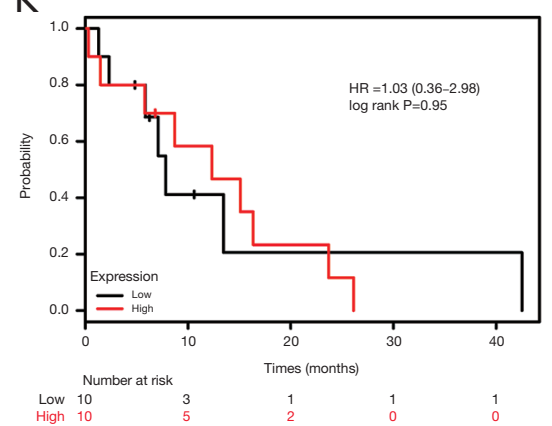

C

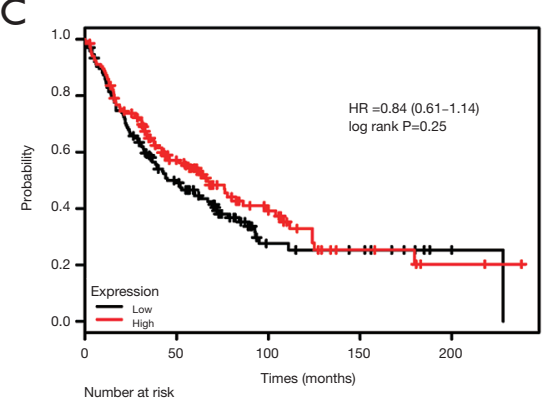

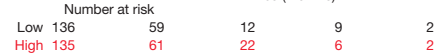

F

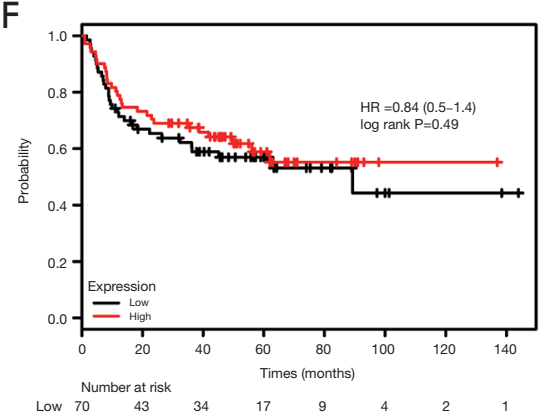

I

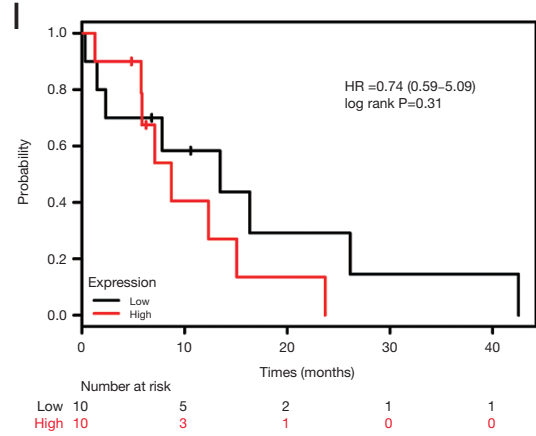

L

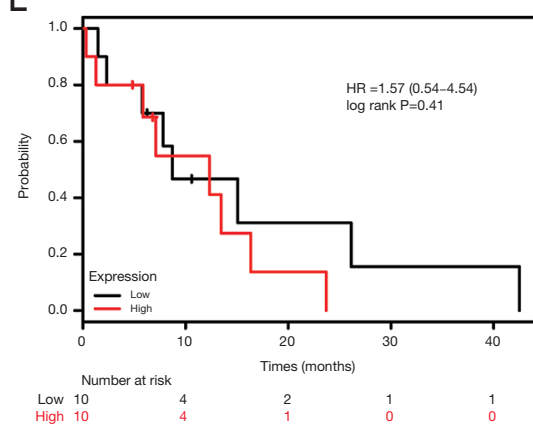

Figure 2 The prognostic roles of 4.1 in squamous cell carcinoma. (A,B,C,D) The relationship of 4.1G, 4.1B, 4.1R, 4.1N with OS. (E,F,G,H) The relationship of 4.1G, 4.1B, 4.1R, 4.1N with FP. (I,J,K,L) The relationship of 4.1G, 4.1B, 4.1R, 4.1N with PPS. HR, hazard ratio; NSCLC, non-small cell lung cancer; OS, overall survival; FP, first progression; PPS, post progression survival. 
4.1G $(\mathrm{HR}=0.65,95 \%$ CI: $0.48-0.89, \mathrm{P}=0.0073), 4.1 \mathrm{~N}$ (HR $=0.68,95 \%$ CI: $0.50-0.94, \mathrm{P}=0.0017)$ and $4.1 \mathrm{R}$ (HR $=0.49,95 \%$ CI: $0.35-0.68, \mathrm{P}=1.4 \mathrm{e}-05$ ) were correlated with FP. However, only high mRNA expression of 4.1R (HR $=0.61,95 \%$ CI: $0.37-0.99, \mathrm{P}=0.045)$ was related to PPS. All these data, to some extent, suggest that only the 4.1B high expression come along with survival benefits in squamous cell carcinoma, and the overexpression of $4.1 \mathrm{R}$ predicted a better prognosis in adenocarcinoma (Figure 3).

\section{Prognostic values of 4.1s in NSCLC according to clinicopathological features and clinical therapy}

We also explored the relationship of 4.1 members with several baseline characteristics such as gender, smoking history, pathological grades, clinical stages, and therapy regimen. The high level of $4.1 \mathrm{G}$ was associated with longer OS, FP and PPS in female, while $4.1 \mathrm{G}$ overexpression merely with better OS in male. In contrast, the high level of 4.1R was related to improved OS, FP and PPS in male. But for female, 4.1R overexpression was only connected with OS, FP. What's more, the high expression of $4.1 \mathrm{~N}$ was found to be an essential indicator for prolonged OS in male, while $4.1 \mathrm{~B}$ was not related to gender. Therefore, $4.1 \mathrm{G}$ high expression may indicate a better prognosis in female, and so does the high level of 4.1R in male though (Table 1).

As shown in Table 2, we collected and analysed the prognostic data of 4.1 family members in smokers and nonsmokers. High mRNA expression of $4.1 \mathrm{G}$ was correlated with longer OS and FP in patients with or without smoking history and was significantly related to PPS in those without smoking history, showing that the high level of $4.1 \mathrm{G}$ may have a protective effect in non-smokers. Furthermore, 4.1B was more possibly linked to better OS and FP. High mRNA expression of $4.1 \mathrm{R}$ was correlated with improvement of OS in all population, where a better FP in patients without smoking history and a better PPS with smoking history can be observed respectively. It is worth noting that, although the 4.1 family was shown to have a protective role in population with NSCLC, high $4.1 \mathrm{~N}$ expression was closely related to poorer PPS in those people without a history of smoking.

High mRNA expression levels of almost the whole 4.1s were associated with OS and the high expression of $4.1 \mathrm{G}$, $4.1 \mathrm{~B}$ and $4.1 \mathrm{R}$ were also related to better OS in patients with stage I and II lung cancer, while the $4.1 \mathrm{~N}$ was only correlated with OS in stage I lung cancer. Regrettably, the relationship between 4.1 members and stage IV lung cancer fails to be found in the database (Table 3).

The 4.1G, 4.1B and 4.1R were significantly linked with better OS and FP in patients with negative surgical margins. Compared with patients treated by chemotherapy, the 4.1G high expression showed a better OS in those people who did not have chemotherapy. In contrast, the $4.1 \mathrm{G}$ high expression had a better OS in patients treated with radiotherapy than those without radiotherapy. All members were not significantly related to PPS and the $4.1 \mathrm{~N}$ was associated with survival in patients who received treatments (Tables 4-6).

\section{Discussion}

4.1G is a membrane skeleton protein, which regulates cell adhesion, spreading, and migration of mouse embryonic fibroblasts through the $\beta 1$ integrin pathway (11). Although the function of $4.1 \mathrm{G}$ is largely undetectable in tumors, based on previous studies, $4.1 \mathrm{G}$ protein has been confirmed to be related to the occurrence and development of tumors. There were $41 \%$ absence of $4.1 \mathrm{G}$ protein expression in ependymomas, and $4.1 \mathrm{G}$ deletions were associated with more aggressive clinical disease, encountered mostly by patients that either died of their tumor or had residual/ recurrent tumor at last follow-up (12). However, there is few researches about the 4.1 family in the process of NSCLC. Our results revealed that $4.1 \mathrm{G}$ is the most prognostically valuable in lung cancer compared to several other family members. No matter in patients with NSCLC or adenocarcinoma lung cancer, excessive $4.1 \mathrm{G}$ expression showed protective potential, especially in female. What's more, in those patients who received surgical treatment with radiotherapy and negative margins which influenced by the surgeon's proficiency in a degree, $4.1 \mathrm{G}$ overexpression leaded to a better OS, which also can be observed in people without chemotherapy treatment.

$4.1 \mathrm{~B}$, as an adaptor protein, located at the junction of cells, can link the cytoplasmic membrane to the cytoskeleton or cytoplasmic effector molecules, and can be involved in modulating cell growth, motility, adhesion, cytoskeleton organization (13). DAL-1 is a short form of $4.1 \mathrm{~B}$ and contains the major functional structure of protein 4.1B. In recent years, several studies have confirmed that $4.1 \mathrm{~B}$, which is considered as a potential negative regulator, is closely connected with the occurrence and development of tumors $(7,14,15)$. However, the controversy still exists. To date, the biological functions of protein $4.1 \mathrm{~B}$ in carcinogenesis remain unknown. Yi et al. (16). demonstrated 
A

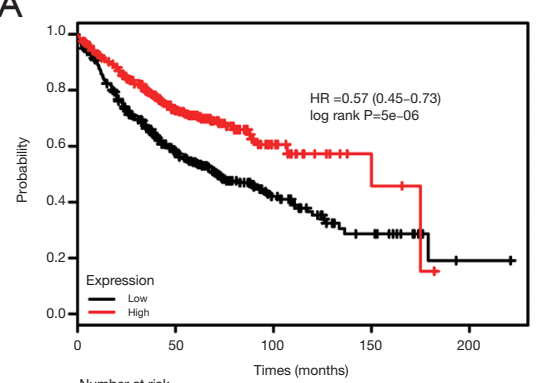

Number at risk
Low 360
High 360

D

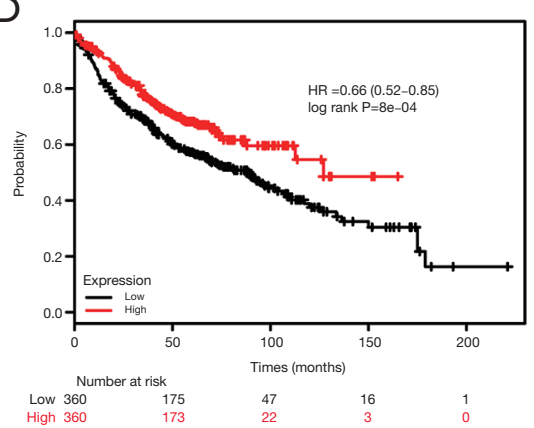

G
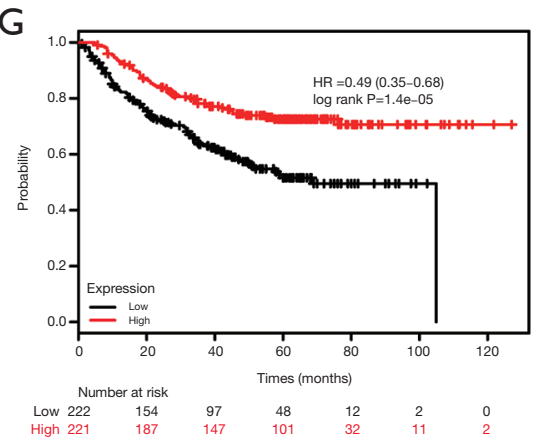

J

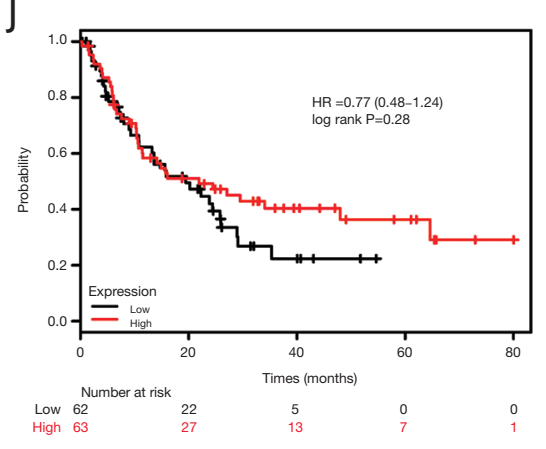

B

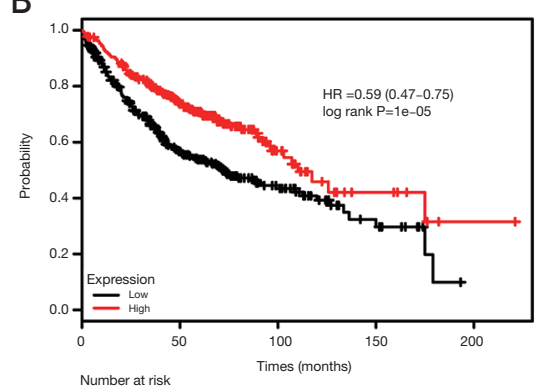

$\begin{array}{lr}\text { Number at risk } \\ \text { Low } 362 & 147 \\ \text { High } 358 & 201\end{array}$

E

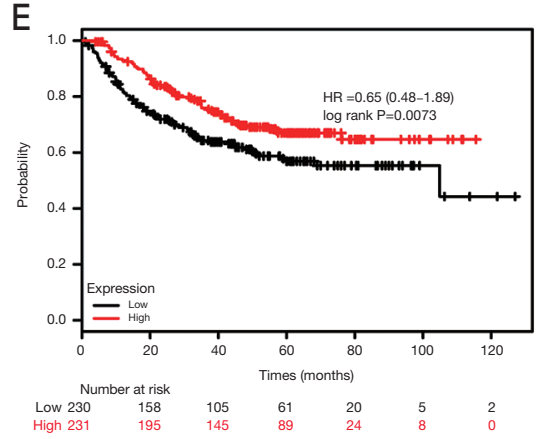

$\mathrm{H}$

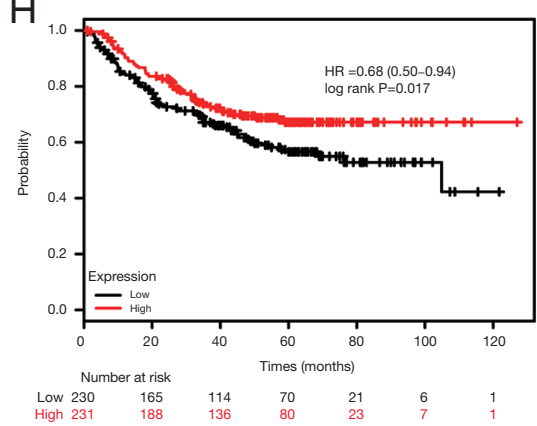

K

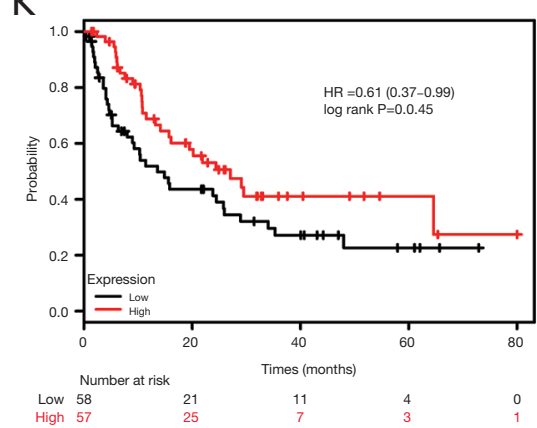

C

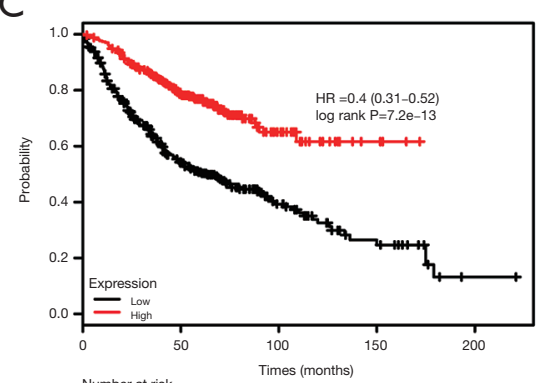

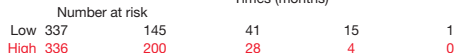

F

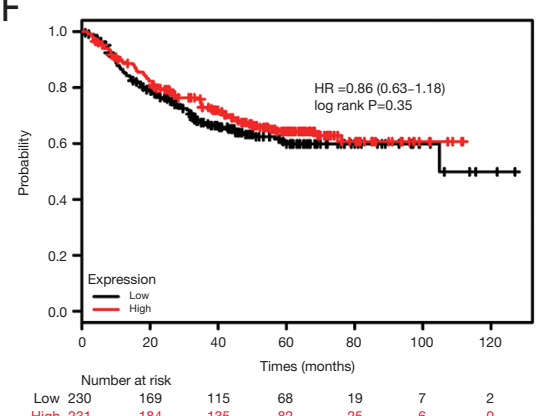

I

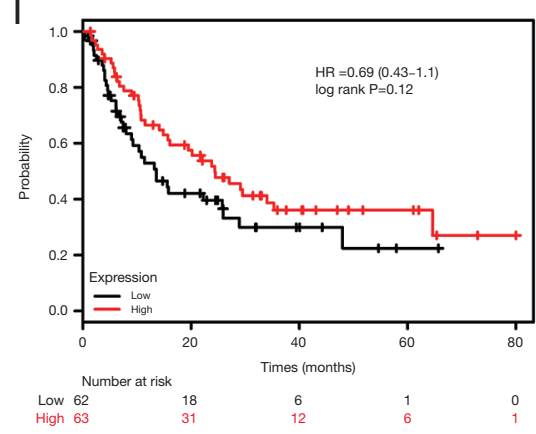

L

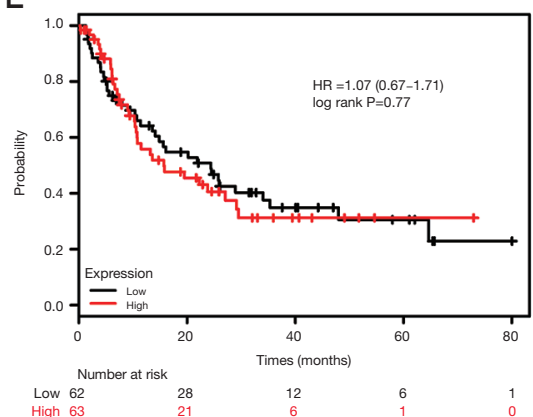

Figure 3 The prognostic roles of 4.1 in adenocarcinoma. (A,B,C,D) The relationship of 4.1G, 4.1B, 4.1R, 4.1N with OS. (E,F,G,H) The relationship of 4.1G, 4.1B, 4.1R, 4.1N with FP. (I,J,K,L) The relationship of 4.1G, 4.1B, 4.1R, 4.1N with PPS. HR, hazard ratio; NSCLC, non-small cell lung cancer; OS, overall survival; FP, first progression; PPS, post progression survival. 
Table 1 Prognostic values of 4.1 members in gender

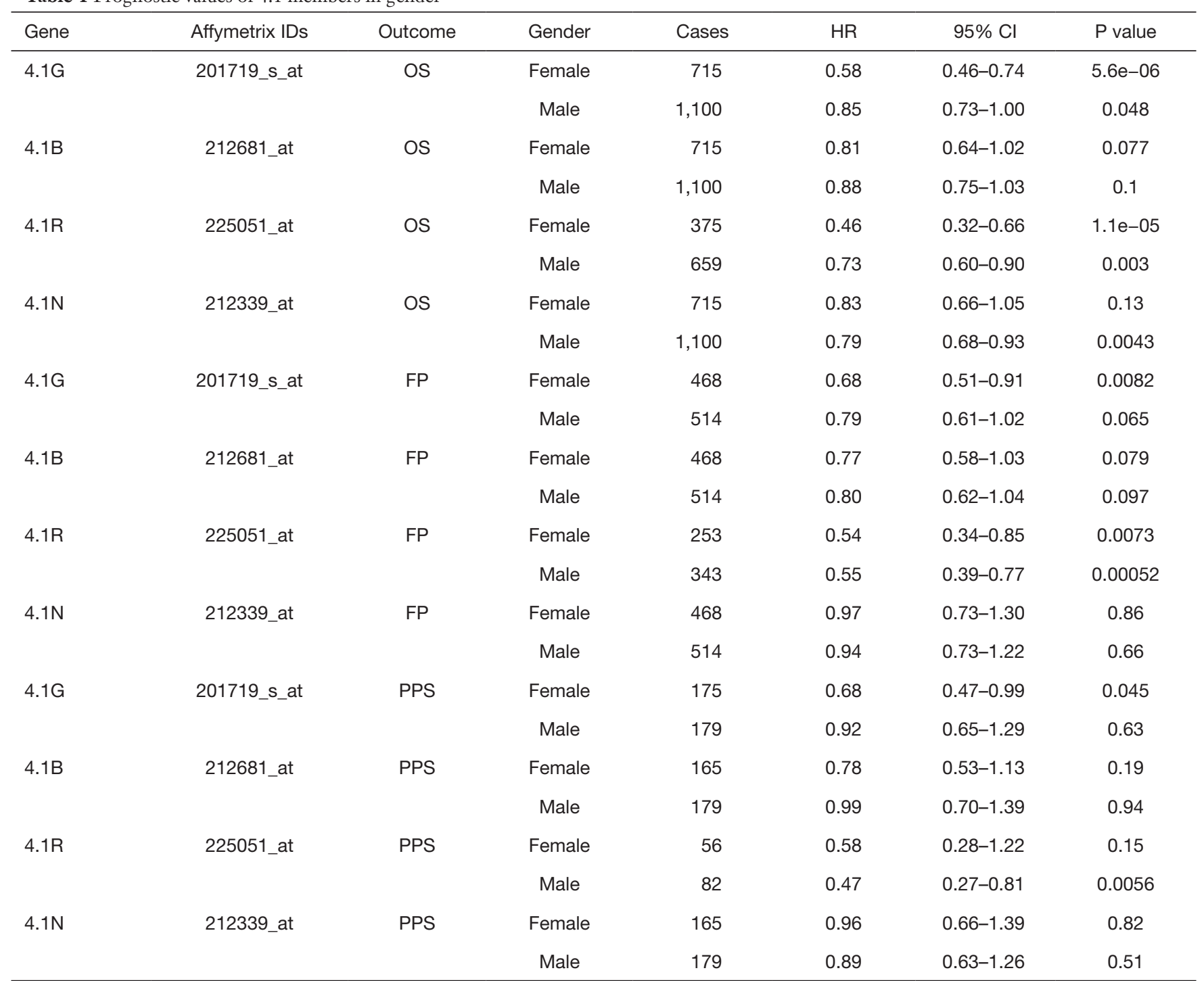

$\mathrm{HR}$, hazard ratio; $\mathrm{Cl}$, confidence interval; OS, overall survival; FP, first progression; PPS, post progression survival.

that the $4.1 \mathrm{~B}$ was not required for normal development and $4.1 \mathrm{~B} / \mathrm{DAL}-1$ did not function as a tumor suppressor gene. Our results revealed that high level 4.1B was linked to better OS, FP, and had advantages in those people who received surgical treatment with negative margins. All these indicates that $4.1 \mathrm{~B}$ was a negative regulator in NSCLC, which was of significant value for prognosis.

Tran et al.(17) reported that 54\% NSCLC showed greatly reduced levels of DAL-1 message, which had no significant differences among adenocarcinomas, squamous, large cell and non-specified NSCLCs. The results of our study showed that whether in squamous cell carcinoma and adenocarcinoma, high expression of 4.1B was correlated with better OS, which corroborated the results of Tran et al. Shinji Kikuchi reported that the methylation was found in $57 \%$ of primary NSCLC and it seemed to be a relatively early event in squamous cell carcinomas, but a late event in adenocarcinoma (18). Loss of DAL-1 expression led by the methylation was also demonstrated to be an important event in the pathogenesis of NSCLC (19). Furthermore, smoking was linked primarily to lung cancer in $90 \%$ of men and $70-80 \%$ of women with lung cancer, which may cause changes in the DNA methylation and gene expression associated with cancer (20). In those patients who never smoked, we reported that high expression 
Table 2 The relationship between prognosis of 4.1 members and smoking status

\begin{tabular}{|c|c|c|c|c|c|c|c|}
\hline Gene & Affymetrix IDs & Outcome & Smoking status & Cases & $\mathrm{HR}$ & $95 \% \mathrm{Cl}$ & $P$ value \\
\hline $4.1 \mathrm{G}$ & & & Never smoked & 205 & 0.32 & $0.17-0.59$ & 0.00012 \\
\hline \multirow[t]{2}{*}{$4.1 \mathrm{~B}$} & 212681_at & OS & Smoked & 820 & 0.91 & $0.74-1.12$ & 0.39 \\
\hline & & & Never smoked & 205 & 0.35 & $0.19-0.64$ & 0.00034 \\
\hline $4.1 \mathrm{R}$ & & & Never smoked & 141 & 0.30 & $0.12-0.76$ & 0.0067 \\
\hline \multirow[t]{2}{*}{$4.1 \mathrm{~N}$} & 212339_at & OS & Smoked & 820 & 1.04 & $0.85-1.28$ & 0.68 \\
\hline & & & Never smoked & 205 & 1.04 & $0.59-1.81$ & 0.9 \\
\hline $4.1 \mathrm{G}$ & 201719_s_at & FP & Smoked & 603 & 0.76 & $0.59-0.97$ & 0.026 \\
\hline $4.1 \mathrm{~B}$ & & & Never smoked & 193 & 0.49 & $0.30-0.80$ & 0.0037 \\
\hline \multirow[t]{2}{*}{$4.1 \mathrm{R}$} & 225051_at & $\mathrm{FP}$ & Smoked & 297 & 0.68 & $0.45-1.00$ & 0.051 \\
\hline & & & Never smoked & 141 & 0.38 & $0.20-0.73$ & 0.0028 \\
\hline \multirow[t]{2}{*}{$4.1 \mathrm{~N}$} & 212339_at & FP & Smoked & 603 & 1.16 & $0.91-1.47$ & 0.24 \\
\hline & & & Never smoked & 193 & 0.63 & $0.38-1.02$ & 0.056 \\
\hline \multirow[t]{2}{*}{$4.1 \mathrm{G}$} & 201719_s_at & PPS & Smoked & 254 & 0.86 & $0.65-1.15$ & 0.32 \\
\hline & & & Never smoked & 67 & 0.35 & $0.18-0.67$ & 0.00095 \\
\hline $4.1 \mathrm{~B}$ & 212681_at & PPS & Smoked & 254 & 1.07 & $0.8-1.42$ & 0.66 \\
\hline
\end{tabular}

$\mathrm{HR}$, hazard ratio; $\mathrm{Cl}$, confidence interval; OS, overall survival; FP, first progression; PPS, post progression survival.

of 4.1B led to better OS and FP, which may be associated with the methylation caused by smoking.

Similar to $4.1 \mathrm{~B}, 4.1 \mathrm{~N}$ can connect transmembrane proteins to the actin cytoskeleton, which plays a vital role in maintaining the stability and integrity of cell membrane. The research on $4.1 \mathrm{~N}$ is mostly focused on the nervous system, whereas it has also been reported that the expression level of $4.1 \mathrm{~N}$ is closely related to the metastasis of tumors (21). Ji et al. (22) reintroduced the 4.1N-deleted breast cancer cell line by transfection with the pEGFP$4.1 \mathrm{~N}$ plasmid, which subsequently reduced breast cancer cell adhesion, invasion, and migration significantly. In addition to this, $4.1 \mathrm{~N}$ reversed epithelial-mesenchymal transition in ovarian cancer by inhibiting the expression of hypoxiainducible factor HIF-1 $\alpha$, and highlighted its potential role in epithelial ovarian cancer (EOC) therapy as an inhibitor of hypoxia-induced tumor progression in EOC cells (23). $4.1 \mathrm{~N}$ is also proved to be involved in the suppression of cell proliferation and migration through a flotillin-1/ $\beta$-catenin/Wnt pathway in NSCLC (24). The data of our study revealed that $4.1 \mathrm{~N}$ had a certain value in the prognosis of NSCLC. Highly expressed 4.1N showed better OS, especially in adenocarcinoma, and better FP. Compared with female, overexpression of $4.1 \mathrm{~N}$ had a prognostic advantage 
Table 3 The relationship between prognosis of 4.1 members and tumor stage

\begin{tabular}{|c|c|c|c|c|c|c|}
\hline Gene & Affymetrix IDs & Stage & Cases & $\mathrm{HR}$ & $95 \% \mathrm{Cl}$ & $P$ value \\
\hline \multirow{2}{*}{$4.1 \mathrm{G}$} & & Stage II & 244 & 0.65 & $0.45-0.94$ & 0.023 \\
\hline & & Stage III & 70 & 1.42 & $0.83-2.44$ & 0.20 \\
\hline \multirow[t]{2}{*}{$4.1 \mathrm{~B}$} & 212681_at & Stage I & 577 & 0.58 & $0.44-0.76$ & $6.1 e-05$ \\
\hline & & Stage III & 70 & 0.88 & $0.51-1.52$ & 0.65 \\
\hline \multirow[t]{3}{*}{$4.1 \mathrm{R}$} & 225051_at & Stage I & 449 & 0.28 & $0.20-0.41$ & $3.6 e-13$ \\
\hline & & Stage II & 161 & 0.61 & $0.38-0.96$ & 0.032 \\
\hline & & Stage III & 44 & 0.91 & $0.46-1.80$ & 0.78 \\
\hline $4.1 \mathrm{~N}$ & & Stage III & 70 & 0.89 & $0.52-1.53$ & 0.67 \\
\hline
\end{tabular}

$\mathrm{HR}$, hazard ratio; $\mathrm{Cl}$, confidence interval.

Table 4 OS of 4.1 expression in treatment

\begin{tabular}{|c|c|c|c|c|c|c|}
\hline Gene & Affymetrix IDs & Treatment & Cases & $H R$ & $95 \% \mathrm{Cl}$ & $P$ value \\
\hline \multirow{3}{*}{$4.1 \mathrm{G}$} & & Chemotherapy: no & 310 & 0.70 & $0.50-0.98$ & 0.037 \\
\hline & & Chemotherapy: yes & 176 & 1.04 & $0.69-1.56$ & 0.86 \\
\hline & & Radiotherapy: no & 276 & 0.71 & $0.49-1.01$ & 0.059 \\
\hline \multirow[t]{4}{*}{$4.1 \mathrm{~B}$} & 212681_at & Surgery (surgical margins negative) & 726 & 0.74 & $0.59-0.93$ & 0.01 \\
\hline & & Chemotherapy: no & 310 & 1.12 & $0.80-1.57$ & 0.50 \\
\hline & & Chemotherapy: yes & 176 & 0.88 & $0.59-1.32$ & 0.55 \\
\hline & & Radiotherapy: no & 271 & 1.24 & $0.87-1.76$ & 0.24 \\
\hline \multirow{2}{*}{$4.1 \mathrm{R}$} & & Chemotherapy: no & 21 & 2.02 & $0.37-11.10$ & 0.41 \\
\hline & & Chemotherapy: yes & 34 & 0.75 & $0.24-2.41$ & 0.63 \\
\hline \multirow[t]{5}{*}{$4.1 \mathrm{~N}$} & 212339_at & Surgery (surgical margins negative) & 726 & 1.09 & $0.87-1.37$ & 0.46 \\
\hline & & Chemotherapy: no & 310 & 0.99 & $0.71-1.38$ & 0.94 \\
\hline & & Chemotherapy: yes & 176 & 0.97 & $0.65-1.45$ & 0.88 \\
\hline & & Radiotherapy: no & 271 & 1.18 & $0.83-1.68$ & 0.36 \\
\hline & & Radiotherapy: yes & 0.78 & 1.44 & $0.45-1.32$ & 0.35 \\
\hline
\end{tabular}

HR, hazard ratio; $\mathrm{Cl}$, confidence interval; OS, overall survival. 
Table 5 FP of 4.1 expression in treatment

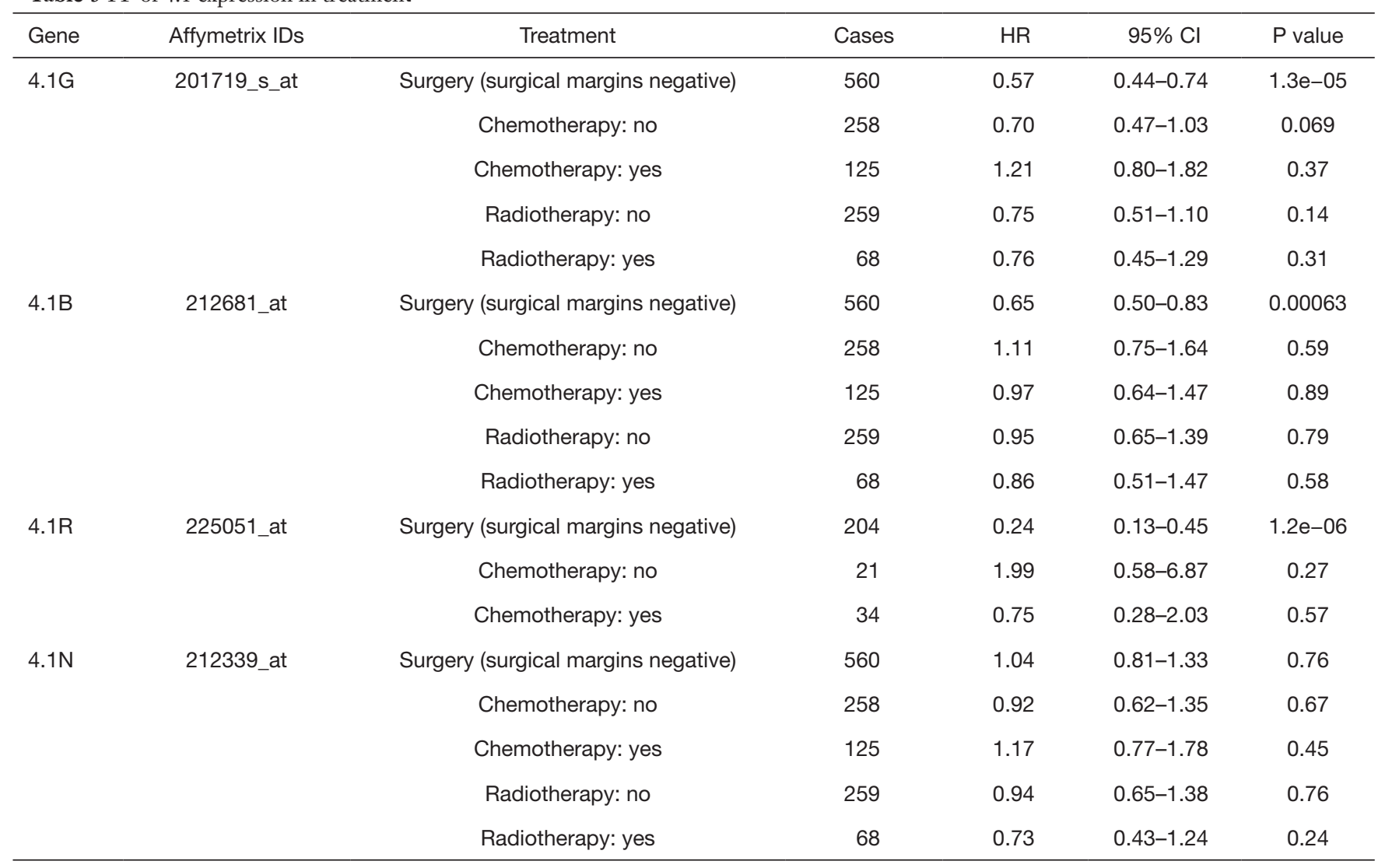

$\mathrm{HR}$, hazard ratio; $\mathrm{Cl}$, confidence interval; FP, first progression.

in male. However, in those patients who never smoked, an excessively high $4.1 \mathrm{~N}$ showed worse PPS. What's more, $4.1 \mathrm{~N}$ did not show prognostic value in treatment.

$4.1 \mathrm{R}$ acts as a multifunctional component of erythrocyte membrane and regulates the junctions of the RBC transmembrane proteins and the spectrin-actin cytoskeleton network (25). Mutations or defects in 4.1R cause instability of the network and consequently the whole cell membrane. 4.1R has been reported to play a number of essential roles. In the gastric epithelial cells, 4.1R associates with adherent junction protein $\beta$-catenin (26). Structural protein $4.1 \mathrm{R}$ is also integrally involved in nuclear envelope protein localization, centrosome-nucleus association and transcriptional signaling (27). Kang et al. reported that 4.1R negatively regulated T-cell activation by inhibiting the phosphorylation of LAT in mouse $\mathrm{CD}^{+} \mathrm{T}$ lymphocytes (28). Even though, the specific mechanism of $4.1 \mathrm{R}$ in tumors still remains unclear, 4.1R had been confirmed to be closely linked to cell migration, and research showed that $40 \%$ of meningioma patients were lack of $4.1 \mathrm{R}$ expression $(29,30)$. The results of our study found that 4.1R overexpression was associated with OS, FP, and PPS in NSCLC, especially in adenocarcinoma and men, in which the prognosis of $4.1 \mathrm{R}$ was most valuable. However, there was still controversy regarding the prognosis of smoking status. Highly expressed 4.1R had a better FP in non-smoking populations, while a better PPS in smoking population. Although there was no significant correlation between the prognosis of patients receiving chemotherapy and radiotherapy, the results also showed that the high expression of $4.1 \mathrm{R}$ was related to patients who received surgical treatment with margins negative.

\section{Conclusions}

We used KM plotter to evaluate the prognostic value of the 4.1 family mRNA expression in NSCLC patients. Even though all 4 family members were associated with the prognosis of NSCLC, the prognostic value should be combined with clinical characteristics and further evaluated in clinical studies. 4.1 proteins, as protective factor for 
Table 6 PPS of 4.1 expression in treatment

\begin{tabular}{|c|c|c|c|c|c|c|}
\hline Gene & Affymetrix IDs & Treatment & Cases & $\mathrm{HR}$ & $95 \% \mathrm{Cl}$ & $P$ value \\
\hline \multirow{3}{*}{$4.1 \mathrm{G}$} & & Chemotherapy: no & 97 & 0.89 & $0.55-1.42$ & 0.61 \\
\hline & & Chemotherapy: yes & 88 & 0.94 & $0.59-1.50$ & 0.80 \\
\hline & & Radiotherapy: no & 104 & 0.86 & $0.55-1.34$ & 0.51 \\
\hline \multirow[t]{4}{*}{$4.1 \mathrm{~B}$} & 212681_at & Surgery (surgical margins negative) & 246 & 0.94 & $0.70-1.27$ & 0.69 \\
\hline & & Chemotherapy: no & 97 & 1.31 & $0.82-2.08$ & 0.26 \\
\hline & & Chemotherapy: yes & 88 & 1.21 & $0.76-1.95$ & 0.42 \\
\hline & & Radiotherapy: no & 104 & 1.03 & $0.67-1.60$ & 0.89 \\
\hline \multirow{2}{*}{$4.1 \mathrm{R}$} & & Chemotherapy: no & 9 & - & - & - \\
\hline & & Chemotherapy: yes & 14 & - & - & - \\
\hline \multirow[t]{5}{*}{$4.1 \mathrm{~N}$} & 212339_at & Surgery (surgical margins negative) & 246 & 1.03 & $0.76-1.38$ & 0.87 \\
\hline & & Chemotherapy: no & 97 & 0.83 & $0.52-1.33$ & 0.45 \\
\hline & & Chemotherapy: yes & 88 & 0.77 & $0.48-1.24$ & 0.28 \\
\hline & & Radiotherapy: no & 104 & 0.78 & $0.50-1.22$ & 0.27 \\
\hline & & Radiotherapy: yes & 57 & 0.87 & $0.49-1.56$ & 0.64 \\
\hline
\end{tabular}

PPS, post progression survival.

cancer treatment, however, the mechanism of 4.1 family in NSCLC is still unclear. Our study was supposed to provide a reference for the prognosis of NSCLC and a potential therapeutic target and contribute to the development of new drugs for NSCLC.

\section{Acknowledgments}

Funding: Zhejiang Provincial Program for the Cultivation of High-Level Innovative Health Talents (Shanming Ruan, No. 2015-43, http://www.zjwjw.gov.cn/); Program for the Cultivation of Youth talents in China Association of Chinese Medicine (Shanming Ruan, No. QNRC2-C08, http://www.cacm.org.cn/); Zhejiang Provincial Program for the Cultivation of the Young and Middle-Aged Academic Leaders in Colleges and Universities (Shanming Ruan, No. 2017-248, http://www.zjedu.gov.cn/); Zhejiang Provincial Project for the key discipline of Traditional Chinese Medicine (Yong Guo, No. 2017-XK-A09, http://www.zjwjw. gov.cn/).

\section{Footnote}

Reporting Checklist: The authors have completed the REMARK reporting checklist. Available at http://dx.doi. org/10.21037/tcr-20-2501

Conflicts of Interest: All authors have completed the ICMJE uniform disclosure form (available at http://dx.doi. org/10.21037/tcr-20-2501). The authors have no conflicts of interest to declare.

Ethical Statement: The authors are accountable for all aspects of the work in ensuring that questions related to the accuracy or integrity of any part of the work are appropriately investigated and resolved. The study was conducted in accordance with the Declaration of Helsinki (as revised in 2013). All data in the database is publicly available and exempt from Institutional Review Board review.

Open Access Statement: This is an Open Access article 
distributed in accordance with the Creative Commons Attribution-NonCommercial-NoDerivs 4.0 International License (CC BY-NC-ND 4.0), which permits the noncommercial replication and distribution of the article with the strict proviso that no changes or edits are made and the original work is properly cited (including links to both the formal publication through the relevant DOI and the license). See: https://creativecommons.org/licenses/by-nc-nd/4.0/.

\section{References}

1. Siegel RL, Miller KD, Jemal A. Cancer statistics, 2018. CA Cancer J Clin 2018;68:7-30.

2. Economopoulou P, Mountzios G. The emerging treatment landscape of advanced non-small cell lung cancer. Ann Transl Med 2018;6:138.

3. Gkolfinopoulos S, Mountzios G. Beyond EGFR and ALK: targeting rare mutations in advanced non-small cell lung cancer. Ann Transl Med 2018;6:142.

4. Diakowski W, Grzybek M, Sikorski AF. Protein 4.1, a component of the erythrocyte membrane skeleton and its related homologue proteins forming the protein 4.1/FERM superfamily. Folia Histochem Cytobiol 2006;44:231-48.

5. Baines AJ, Lu HC, Bennett PM. The Protein 4.1 family: hub proteins in animals for organizing membrane proteins. Biochim Biophys Acta 2014;1838:605-19.

6. Busam RD, Thorsell AG, Flores A, et al. Structural basis of tumor suppressor in lung cancer 1 (TSLC1) binding to differentially expressed in adenocarcinoma of the lung (DAL-1/4.1B). J Biol Chem 2011;286:4511-6.

7. Takahashi $Y$, Iwai M, Kawai T, et al. Aberrant expression of tumor suppressors CADM1 and 4.1B in invasive lesions of primary breast cancer. Breast Cancer 2012;19:242-52.

8. Zhu L, Yang N, Chen J, et al. LINC00052 upregulates EPB41L3 to inhibit migration and invasion of hepatocellular carcinoma by binding miR-452-5p. Oncotarget 2017;8:63724-37.

9. Schulz WA, Ingenwerth M, Djuidje CE, et al. Changes in cortical cytoskeletal and extracellular matrix gene expression in prostate cancer are related to oncogenic ERG deregulation. BMC Cancer 2010;10:505.

10. Györffy B, Surowiak P, Budczies J, et al. Online survival analysis software to assess the prognostic value of biomarkers using transcriptomic data in non-small-cell lung cancer. PLoS One 2013;8:e82241. Erratum in: PLoS One. 2014;9(10):e111842.

11. Chen L, Wang T, Wang Y, et al. Protein 4.1G Regulates
Cell Adhesion, Spreading, and Migration of Mouse Embryonic Fibroblasts through the $\beta 1$ Integrin Pathway. J Biol Chem 2016;291:2170-80.

12. Rajaram V, Gutmann DH, Prasad SK, et al. Alterations of protein 4.1 family members in ependymomas: a study of 84 cases. Mod Pathol 2005;18:991-7.

13. Wang $Z$, Zhang J, Ye $M$, et al. Tumor suppressor role of protein 4.1B/DAL-1. Cell Mol Life Sci 2014;71:4815-30.

14. Gerber MA, Bahr SM, Gutmann DH. Protein 4.1B/ differentially expressed in adenocarcinoma of the lung- 1 functions as a growth suppressor in meningioma cells by activating Rac1-dependent c-Jun-NH(2)-kinase signaling. Cancer Res 2006;66:5295-303.

15. Gutmann DH, Hirbe AC, Huang ZY, et al. The protein 4.1 tumor suppressor, DAL-1, impairs cell motility, but regulates proliferation in a cell-type-specific fashion. Neurobiol Dis 2001;8:266-78.

16. Yi C, McCarty JH, Troutman SA, et al. Loss of the putative tumor suppressor band 4.1B/Dal1 gene is dispensable for normal development and does not predispose to cancer. Mol Cell Biol 2005;25:10052-9.

17. Tran YK, Bögler O, Gorse KM, et al. A novel member of the NF2/ERM/4.1 superfamily with growth suppressing properties in lung cancer. Cancer Res 1999;59:35-43.

18. Kikuchi S, Yamada D, Fukami T, et al. Promoter methylation of DAL-1/4.1B predicts poor prognosis in non-small cell lung cancer. Clin Cancer Res 2005;11:2954-61.

19. Heller G, Fong KM, Girard L, et al. Expression and methylation pattern of TSLC1 cascade genes in lung carcinomas. Oncogene 2006;25:959-68.

20. Al-Obaide MAI, Ibrahim BA, Al-Humaish S, et al. Genomic and Bioinformatics Approaches for Analysis of Genes Associated with Cancer Risks Following Exposure to Tobacco Smoking. Front Public Health 2018;6:84.

21. Xi C, Ren C, Hu A, et al. Defective expression of Protein $4.1 \mathrm{~N}$ is correlated to tumor progression, aggressive behaviors and chemotherapy resistance in epithelial ovarian cancer. Gynecol Oncol 2013;131:764-71.

22. Ji Z, Shi X, Liu X, et al. The membrane-cytoskeletal protein $4.1 \mathrm{~N}$ is involved in the process of cell adhesion, migration and invasion of breast cancer cells. Exp Ther Med 2012;4:736-40.

23. Zhang L, Hu A, Li M, et al. 4.1N suppresses hypoxiainduced epithelial-mesenchymal transition in epithelial ovarian cancer cells. Mol Med Rep 2016;13:837-44.

24. Yang $\mathrm{Q}$, Zhu $M$, Wang $Z$, et al. $4.1 \mathrm{~N}$ is involved in a flotillin-1/ $\beta$-catenin/Wnt pathway and suppresses cell 
proliferation and migration in non-small cell lung cancer cell lines. Tumour Biol 2016;37:12713-23.

25. Zhang DQ, Wang YP, Wang WH, et al. Interaction between protein 4.1R and spectrin heterodimers. Mol Med Rep 2011;4:651-4.

26. Yang S, Guo X, Debnath G, et al. Protein 4.1R links E-cadherin/beta-catenin complex to the cytoskeleton through its direct interaction with beta-catenin and modulates adherens junction integrity. Biochim Biophys Acta 2009;1788:1458-65.

27. Meyer AJ, Almendrala DK, Go MM, et al. Structural protein $4.1 \mathrm{R}$ is integrally involved in nuclear envelope

Cite this article as: Xiang Y, Shan F, Feng G, Guo K, Ruan $\mathrm{S}$, Huang D. The prognostic value of $4.1 \mathrm{mRNA}$ expression in non-small cell lung cancer. Transl Cancer Res 2021;10(3):12161228. doi: 10.21037/tcr-20-2501 protein localization, centrosome-nucleus association and transcriptional signaling. J Cell Sci 2011;124:1433-44.

28. Kang Q, Yu Y, Pei X, et al. Cytoskeletal protein 4.1R negatively regulates $T$-cell activation by inhibiting the phosphorylation of LAT. Blood 2009;113:6128-37.

29. Ruiz-Sáenz A, Kremer L, Alonso MA, et al. Protein 4.1R regulates cell migration and IQGAP1 recruitment to the leading edge. J Cell Sci 2011;124:2529-38.

30. A Perry, DH Gutmann, G Reifenberger. Molecular pathogenesis of meningiomas. J Neurooncol 2004;70:183-202. 